\title{
Effect of antihypertensive treatment on kidney function in diabetic nephropathy
}

\author{
HANS-HENRIK PARVING, ALLAN R ANDERSEN, ULLA M SMIDT, EVA HOMMEL, \\ ELISABETH R MATHIESEN, PER A SVENDSEN
}

\begin{abstract}
The effect of long term, aggressive antihypertensive treatment on kidney function in diabetic nephropathy was studied prospectively in 11 insulin dependent diabetics (mean age 30). During the mean pretreatment period of 32 (range 23-66) months the glomerular filtration rate decreased significantly and albuminuria and the arterial blood pressure increased significantly. During the 72 (range 32-91) month period of antihypertensive treatment the average arterial blood pressure fell from $143 / 96 \mathrm{~mm} \mathrm{Hg}$ to $129 / 84 \mathrm{~mm} \mathrm{Hg}$ and albuminuria decreased from $1038 \mu \mathrm{g} / \mathrm{min}$ to $504 \mu \mathrm{g} / \mathrm{min}$. The rate of decline in the glomerular filtration rate decreased from 0.89 (range $0.44-1.46$ ) $\mathrm{ml} / \mathrm{min} / \mathrm{month}$ before treatment to 0.22 (range $0.01-0.40) \mathrm{ml} / \mathrm{min} / \mathrm{month}$ during treatment. The rate of decline in the glomerular filtration rate was significantly smaller during the second three years compared with the first three years in patients who received long term antihypertensive treatment ( $\geqslant 6$ years). One patient died from acute myocardial infarction (glomerular filtration rate $46 \mathrm{ml} / \mathrm{min} /$ $1.74 \mathrm{~m}^{2}$ ).
\end{abstract}

Effective antihypertensive treatment postpones renal insufficiency in diabetic nephropathy.

Hvidöre Hospital, Klampenborg, Denmark

HANS-HENRIK PARVING, MD, chief physician

ALLAN R ANDERSEN, MD, registrar

EVA HOMMEL, MD, registrar

ELISABETH R MATHIESEN, MD, registrar

Department of Clinical Physiology, Bispebjerg Hospital, Denmark

ULLA M SMIDT, laboratory technician

Steno Memorial Hospital, Gentofte, Denmark

PER A SVENDSEN, pharmacist

Correspondence to: Dr H-H Parving, Hvidöre Hospital, Emiliekildevej 1, DK-2930, Klampenborg, Denmark.

\section{Introduction}

About $40 \%$ of all insulin dependent diabetic patients develop persistent proteinuria, a decline in their glomerular filtration rate, and increased blood pressure, collectively constituting the clinical syndrome of diabetic nephropathy..$^{2}$ Recent studies have shown that mortality in insulin dependent diabetic patients who have persistent proteinuria is much higher than in diabetics without proteinuria, reaching a maximum mortality of 80 times that in the non-diabetic background population. ${ }^{3}$

Renal failure is the main cause of death in insulin dependent diabetic patients who have nephropathy. Increased blood pressure accelerates the development of diabetic glomerulopathy in $\operatorname{man}^{4}$ and in diabetic rats. ${ }^{5}$ In 1982 Mogensen showed that antihypertensive treatment slowed the rate of decline in the renal function of five men who had insulin dependent diabetes and diabetic nephropathy ${ }^{6}$

The aims of our prospective study, which began in 1976, were to determine the initial clinical course of diabetic nephropathy ${ }^{7}$ and to evaluate the long term effect of aggressive treatment of increased blood pressure on the glomerular filtration rate and albuminuria in patients who had insulin dependent diabetes and diabetic nephropathy. An interim report of this "self controlled" study was published in $1983 .^{8}$

Patients and methods

\section{PATIENTS}

Fourteen insulin dependent diabetic patients who had diabetic nephropathy were initially included in our prospective study of the clinical course of diabetic nephropathy, as described. ${ }^{7}$ One man left the study when he was admitted to a nursing home after a stroke, and another man was excluded because diabetic nephropathy was unlikely to have been the cause of his renal disease. ${ }^{8}$

The remaining 12 patients were investigated (table I) after they had given their fully informed consent. Their diabetic diet was unchanged during the study, and none of the patients had their intake of salt or protein restricted. Only one patient was taking drugs (case 11); she was receiving phenytoin (300-400 mg/day) for epilepsy. The experimental design was approved by the local ethical committee. 
Antihypertensive treatment was started after a control period of at least 23 months if repeated measurements showed a diastolic blood pressure $\geqslant 100 \mathrm{~mm} \mathrm{Hg}$ (eight patients) or if the patient had a sustained diastolic blood pressure of $\geqslant 90 \mathrm{~mm} \mathrm{Hg}$ preceded by an increase in mean arterial blood pressure of $\geqslant 10 \mathrm{~mm} \mathrm{Hg}$ during the past two years (four patients). Metoprolol, hydralazine, and frusemide or thiazide were used as antihypertensive drugs (table I). One patient (case 5) did not receive metoprolol

\section{Results}

The arterial blood pressure and albuminuria increased in all patients during the control period $(p<0 \cdot 01$, table II, fig 1). During treatment, however, the arterial blood pressure decreased in 11 of the 12 treated patients, and albuminuria decreased in 10 of the 11 effectively treated patients $(p<0.01$, table II). In case 11 , which is discussed separately, as the

TABLE I-Clinical data from 12 patients who had insulin dependent diabetes and nephropathy

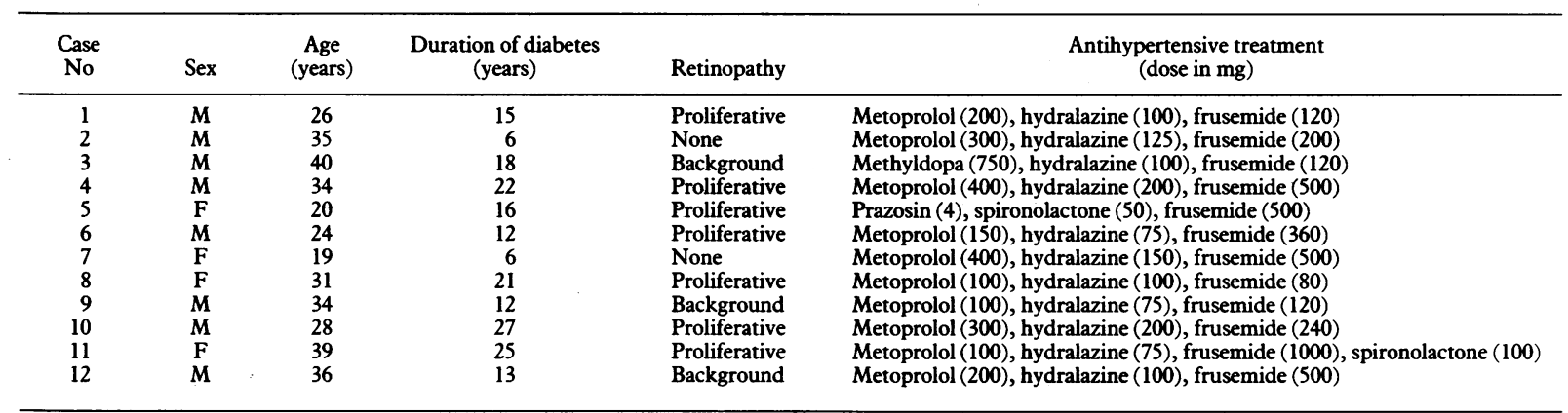

because of a complete lack of hypoglycaemic warning signs, and treatment with metoprolol was stopped after two years in case 3 because the patient suffered two hypoglycaemic attacks that required treatment with intravenous glucose. Methyldopa and prazosin were used in these patients. The aim of the antihypertensive treatment was a stable reduction in the mean arterial blood pressure (diastolic pressure plus one third of the pulse amplitude) of at least $10 \mathrm{~mm} \mathrm{Hg}$.

\section{METHODS}

All investigations were carried out on one day between 9 am and $1 \mathrm{pm}$. Patients had their normal breakfast and morning insulin dose before the studies, during which they were resting in a supine position. The investigations were carried out four to 13 (mean five) times over 2366 months before antihypertensive treatment and nine to 23 (mean 18) times during the subsequent 32-91 months of treatment.

To measure the glomerular filtration rate we gave the patients a single intravenous injection of $100 \mu \mathrm{Ci}$ sodium chromate-51 edetic acid at 9 am and determined the plasma radioactivity in venous blood samples taken from the other arm 180, 200, 220, and 240 minutes after the injection. ${ }^{910}$ The small underestimation $(10 \%)$ of ${ }^{51} \mathrm{Cr}$-edetic acid clearance versus clearance of inulin was corrected for by multiplying the chromate clearance by $1 \cdot 10 .^{10}$ The results were standardised for $1.73 \mathrm{~m}^{2}$ body surface area, using the patients' surface area at the start of the study throughout. The mean coefficient of variation in the glomerular filtration rate of each patient from day to day was $4 \%$.

Urinary albumin excretion was measured by radial immunodiffusion ${ }^{11}$ during the four hour clearance period. The blood pressure was taken with a standard clinical sphygmomanometer (cuff $25 \mathrm{~cm} \times 12 \mathrm{~cm}$ ) on the right arm, the patient having been in the supine position for at least 10 minutes. The blood pressure was measured twice during each investigation and visit to the outpatient clinic. The diastolic blood pressure was taken to be the point at which the Korotkoff sounds disappeared (phase V).

The patients visited the clinic every two to four months during the investigation (mean 9.3 years). At each visit the postprandial blood glucose concentration was measured (with a glucose oxidase method), along with glucosuria, proteinuria, blood pressure, and body weight, and the insulin dose and antihypertensive treatment were adjusted. Ophthalmoscopy was carried out on dilated pupils at least every six to 12 months by one of us (ARA).

\section{STATISTICAL ANALYSIS}

Wilcoxon's non-parametric test for paired comparisons (two tailed) was used. All the results before antihypertensive treatment were compared with all those during effective treatment. The rate of decline in glomerular filtration rate $(\mathrm{ml} / \mathrm{min} / \mathrm{month})$ was calculated by linear regression analysis (least squares method). The values given are means (SEM).

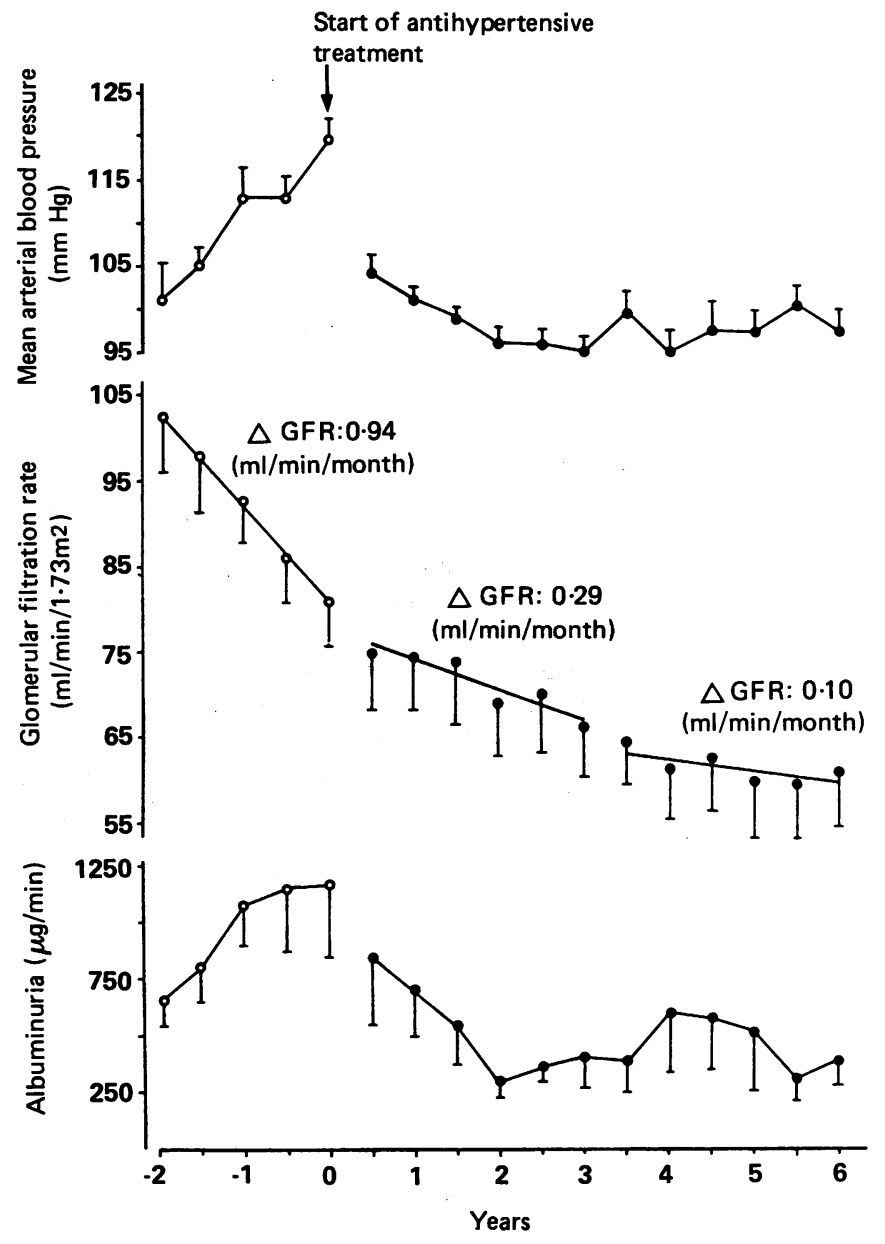

FIG 1-Average course of mean arterial blood pressure, glomerular filtration rate, and albuminuria before $(O)$ and during $(O)$ long term effective antihypertensive treatment of nine insulin dependent diabetic patients who had nephropathy.

patient's blood pressure increased during treatment, the concentration of albumin in the urine was nearly twice as high during treatment as before. In one patient (case 4) who died from acute myocardial infarction after 35 months of antihypertensive treatment the kidney function was well preserved, the glomerular filtration rate being $46 \mathrm{ml} / \mathrm{min} / 1 \cdot 73 \mathrm{~m}^{2}$.

During treatment the rate of decline in the glomerular filtration rate 
TABLE II-Course of arterial blood pressure, glomerular filtration rate, and albuminuria before and during antihypertensive treatment for diabetic nephropathy. Values are means (SEM)

\begin{tabular}{|c|c|c|c|c|c|c|c|c|}
\hline \multirow{2}{*}{$\begin{array}{l}\text { Case } \\
\text { No }\end{array}$} & \multicolumn{2}{|c|}{$\begin{array}{l}\text { Investigation period } \\
\text { (months) }\end{array}$} & \multicolumn{2}{|c|}{$\begin{array}{l}\text { Blood pressure } \\
\quad(\mathrm{mm} \mathrm{Hg})\end{array}$} & \multicolumn{2}{|c|}{$\begin{array}{l}\text { Decrease in glomerular filtration rate } \\
(\mathrm{ml} / \mathrm{min} / \mathrm{month})\end{array}$} & \multicolumn{2}{|c|}{$\underset{(\mu \mathrm{g} / \mathrm{min})}{\text { Albuminuria }}$} \\
\hline & Before treatment & During treatment & Before treatment & During treatment & Before treatment & During treatment & Before treatment & During treatment \\
\hline $\begin{array}{l}1 \\
2 \\
3 \\
4 \dagger \\
5 \\
6 \\
7 \\
8 \\
9 \\
10 \\
11 \ddagger \\
12\end{array}$ & $\begin{array}{l}27 \\
25 \\
24 \\
29 \\
23 \\
38 \\
36 \\
29 \\
33 \\
23 \\
41 \\
66\end{array}$ & $\begin{array}{l}84 \\
91 \\
87 \\
33 \\
87 \\
72 \\
75 \\
84 \\
78 \\
74 \\
75 \\
32\end{array}$ & $\begin{array}{l}141 / 88(3 / 3) \\
148 / 108(3 / 3) \\
149 / 96(5 / 3) \\
149 / 108(5 / 2) \\
143 / 101(1 / 1) \\
140 / 91(4 / 2) \\
126 / 90(2 / 4) \\
142 / 90(2 / 3) \\
151 / 98(5 / 3) \\
153 / 98(3 / 1) \\
151 / 85(2 / 1) \\
133 / 90(2 / 1)\end{array}$ & $\begin{array}{l}129 / 74(1 / 1) \\
125 / 87(1 / 1) \\
133 / 84(1 / 1) \\
132 / 98(2 / 1) \\
118 / 82(1 / 1) \\
136 / 88(1 / 1) \\
126 / 82(1 / 1) \\
133 / 79(2 / 1) \\
135 / 85(1 / 1) \\
134 / 83(2 / 1) \\
161 / 84(2 / 1) \\
128 / 86(2 / 1)\end{array}$ & $\begin{array}{l}0.77 \\
0.90 \\
0 \cdot 70 \\
1.42 \\
1.46 \\
1.08 \\
0.86 \\
0.82 \\
0.44 \\
0.61 \\
0.64 \\
0.74\end{array}$ & $\begin{array}{l}0.01 \\
0 \cdot 26 \\
0.28 \\
0.40 \\
0 \cdot 10 \\
0.21 \\
0.01 \\
0.34 \\
0.39 \\
0.35 \\
0.59 \\
0.02\end{array}$ & $\begin{array}{c}803(248) \\
1131(90) \\
633(60) \\
1466(430) \\
285(107) \\
1094(254) \\
1021(166) \\
546(98) \\
782(196) \\
2007(493) \\
1791(190) \\
1649(401)\end{array}$ & $\begin{array}{c}649(138) \\
468(44) \\
187(32) \\
328(40) \\
93(19) \\
1250(222) \\
344(64) \\
291(36) \\
566(131) \\
668(93) \\
3539(267) \\
699(76)\end{array}$ \\
\hline Mean (SEM) & $32(4)$ & $72(7)$ & $143 / 96(3 / 2)$ & $129 / 84(2 / 2)$ & $0.89(0.1)$ & $0.225(0.05)$ & $1038(155)$ & $504(97)$ \\
\hline
\end{tabular}

*Average of all determinations before and during treatment.

†Died from acute myocardial infarction after 35 months of antihypertensive treatment.

Insufficiently treated and excluded from mean values and from analyses of effect of antihypertensive treatment on kidney.

$\oint \mathrm{p}<0.01$.

decreased in all 11 effectively treated patients; the rate of decline in the patient in case 11 remained about the same owing to insufficient treatment. Figure 1 shows the average course of arterial blood pressure and kidney function in the nine patients who received long term $(\geqslant 6$ years) antihypertensive treatment. The arterial blood pressure and albuminuria increased progressively during the control period $(p<0.01)$, whereas significant and rather stable reductions occurred during the treatment period $(p<0 \cdot 01)$. Antihypertensive treatment induced a progressive reduction in the rate of decline in glomerular filtration rate (table III), which remained unchanged in one patient and increased in one patient, while the remaining seven patients had lower values during the second three years of treatment compared with the first three years $(\mathrm{p}<0 \cdot 02$, table III): The mean arterial blood pressure, albuminuria, and postprandial blood glucose concentration were about the same during the first and second treatment periods.

Figure 2 shows the individual time courses of glomerular filtration rate in all 12 patients. There was a close linear correlation between glomerular filtration rate and time before treatment (mean $r=0.92$; range $0.82-0.97$ ), but this correlation was weaker and completely lacking in four patients (cases 1, 5, 7, and 12) during treatment (mean $\mathrm{r}=0.68$; range $0.01-0.91$ ). Five patients (cases $4,6,7,10$, and 12) showed a pronounced reduction in glomerular filtration rate shortly after starting antihypertensive treatment, while in two patients (cases 8 and 10) the glomerular filtration rate dropped rather suddenly after several years of antihypertensive treatment.

The rate of decline in glomerular filtration rate in the patient in case 11 was more pronounced during the first three years (mean arterial blood pressure $112 \mathrm{~mm} \mathrm{Hg}$ ) than in the second three years (mean arterial blood pressure $108 \mathrm{~mm} \mathrm{Hg}$ ) of treatment. We did not find any significant correlation between the rate of decline in glomerular filtration rate and the systolic, diastolic, or mean blood pressures either before or during treatment.
TABLE IV-Comparison of glomerular filtration rate at end of observation period after antihypertensive treatment and predicted value after no treatment

\begin{tabular}{ccc}
\hline & \multicolumn{2}{c}{$\begin{array}{c}\text { Glomerular filtration rate } \\
\left(\mathrm{m}^{\prime} / \mathrm{min} / \mathbf{1} \cdot \mathbf{7 3} \mathrm{m}^{2}\right)\end{array}$} \\
\cline { 2 - 3 } Case No & Predicted & Actual \\
\hline 1 & 22 & 81 \\
2 & 0 & 37 \\
3 & 25 & 64 \\
4 & 30 & 46 \\
5 & 0 & 71 \\
6 & 5 & 54 \\
7 & 32 & 60 \\
8 & 15 & 69 \\
9 & 61 & 63 \\
10 & 6 & 24 \\
11 & 38 & 33 \\
12 & 48 & 54 \\
\hline Median† & 22 & $60 \pm$ \\
Range & $0-48$ & $24-81$ \\
\end{tabular}

^Predicted from the rate of decline in glomerular filtration rate before treatment, assuming unchanged slope during whole observation period (median $9 \cdot 3$ years).

tPatient in case 11 (insufficiently treated) is excluded from median value and from analyses of effect of antihypertensive treatment on glomerular filtration rate. $\ddagger \mathrm{p}<0 \cdot 01$.

TABLE III-Course of glomerular filtration rate, mean arterial blood pressure, albuminuria, and blood glucose concentration during long term antihypertensive treatment for diabetic nephropathy in nine patients. Values are means (SEM)

\begin{tabular}{ccccc}
\hline $\begin{array}{c}\text { Treatment period } \\
\text { (years) }\end{array}$ & $\begin{array}{c}\text { Decrease in glomerular filtration rate } \\
(\mathrm{ml} / \mathrm{min} / \mathrm{month})\end{array}$ & $\begin{array}{c}\text { Mean arterial blood pressure } \\
(\mathrm{mm} \mathrm{Hg})\end{array}$ & $\begin{array}{c}\text { Albuminuria } \\
(\mu \mathrm{g} / \mathrm{min})\end{array}$ & $\begin{array}{c}\text { Blood glucose concentration } \\
(\mathrm{mmol} / \mathrm{l})\end{array}$ \\
\hline $0-3$ & $0 \cdot 29(0 \cdot 07)$ & $98 \cdot 5(2)$ & $531(107)$ & $10 \cdot 1(0 \cdot 7)$ \\
$(5-6$ & $0 \cdot 10(0 \cdot 04)^{\star}$ & $98 \cdot 3(1)$ & $472(59)$ & $10 \cdot 0(0 \cdot 6)$ \\
\hline
\end{tabular}

${ }^{\star} \mathrm{p}<0.02$.

Table IV compares the measured glomerular filtration rates at the end of the antihypertensive treatment period with those predicted from the individual rates of decline in glomerular filtration rate before treatment.

There were no changes in mean postprandial blood glucose concentration $(11.0(1.0) \mathrm{mmol} / \mathrm{l}$ before treatment $v 10.4(0.8) \mathrm{mmol} / \mathrm{l}$ during treatment) or daily insulin dose (36 (4) IU before treatment $v 37$ (2) IU during treatment) during the study. The diet and body weight of the patients $(65$ (2) $\mathrm{kg}$ before treatment $v 65$ (2) kg during treatment) were also unchanged. Four patients were initially treated with bendrofluazide, but this was stopped when treatment with frusemide became necessary to control fluid retention and arterial blood pressure. Several patients suffered from intermittent peripheral oedema, but only one (case 11) had persistent oedema during the whole treatment period.

Retinopathy progressed in all 11 effectively treated patients, and nine patients required laser treatment because of proliferative retinopathy (eight patients) and maculopathy (one). The two patients who did not have retinopathy at the start of the study both progressed to background retinopathy. One patient (case 6) became blind. 

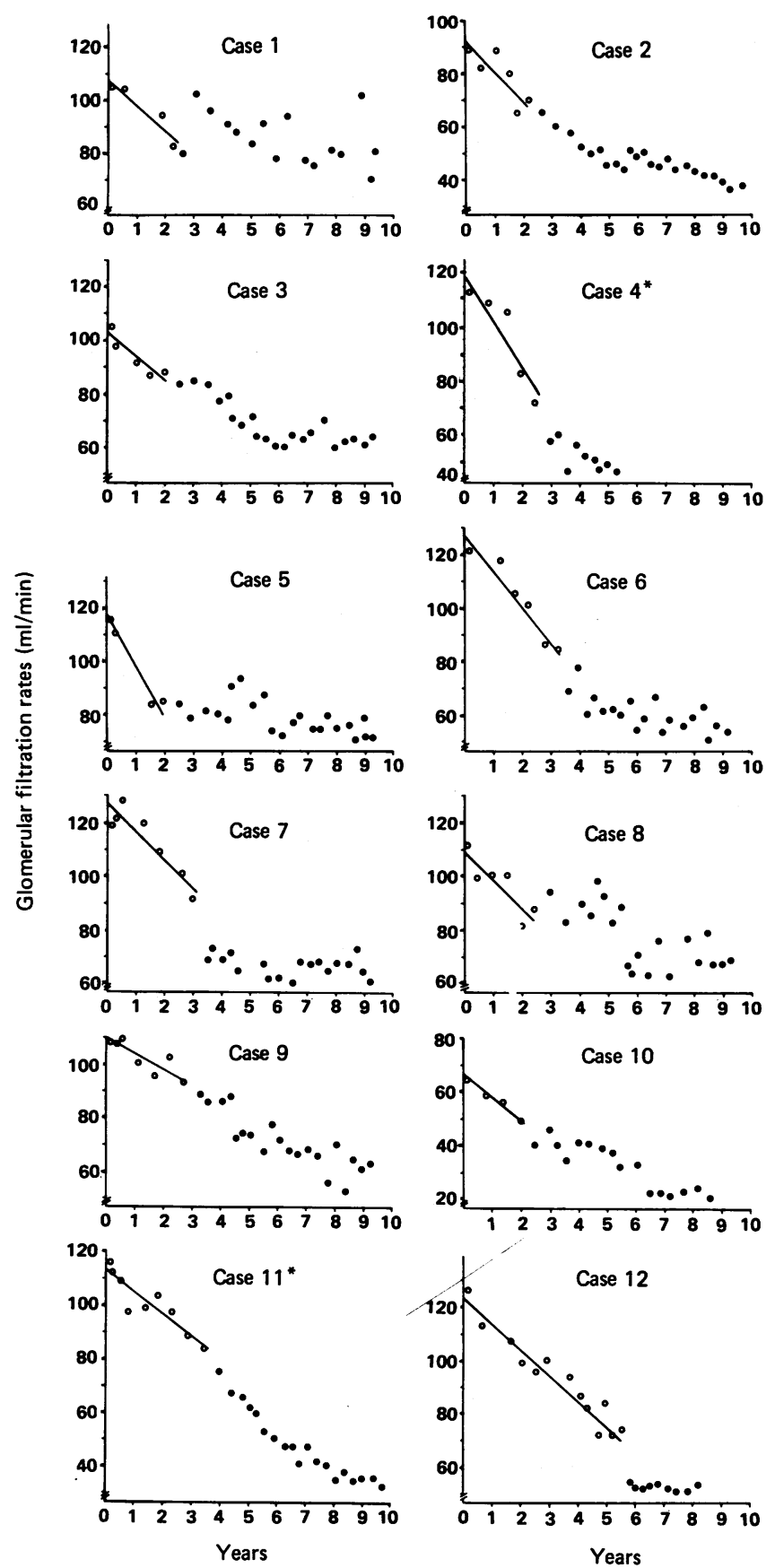

FIG 2-Individual courses of glomerular filtration rate before $(O)$ and during $(O)$ antihypertensive treatment. $\star$ Patient in case 4 died from acute myocardial infarction, and patient in case 11 was insufficiently treated.

\section{Discussion}

Our prospective study has shown that long term, aggressive antihypertensive treatment induces a progressive reduction in the rate of decline in kidney function, thus postponing renal insufficiency in insulin dependent diabetic patients who have diabetic nephropathy. This finding confirms and extends those of Mogensen ${ }^{6}$ and Björck et $a l^{12}$ and our own preliminary observations. ${ }^{8}$

This and the two previous antihypertensive treatment trials in diabetic nephropathy were conducted as self controlled studies, in which each patient served as his or her own control. This design was applied because it was considered to be unethical to use a parallel, untreated hypertensive group of patients who had diabetic nephropathy and because prognostic evaluations can be made from the slope of the decrease in glomerular filtration rate, as discussed below. The validity of such a prediction depends on the precision of the method used for determining the glomerular filtration rate. The precision of our method was $4 \%$.

All of our patients showed a relentless decline in glomerular filtration rate during the control period, in agreement with the results obtained in numerous studies dealing with insulin dependent $\frac{3}{\$}$ diabetic patients suffering from diabetic nephropathy (glomerular $\stackrel{\varnothing}{\varsigma}$ filtration rate range $140-5 \mathrm{ml} / \mathrm{min} / 1 \cdot 73 \mathrm{~m}^{2}{ }^{6}{ }^{12-18}$ The results from this and the previous studies suggest that prognostic evaluations can be $\stackrel{\rho}{\bar{F}}$ made from the slope of the decline in the glomerular filtration rate, $\vec{J}$ as the decline is linear with time and characteristic of the individual patient, though it varies among patients. The same finding of a $m$ constant progression in worsening kidney function in individual $\varrho$ patients has been obtained in studies of various other renal $\overrightarrow{\vec{F}}$ diseases. ${ }^{19}$

The average decline in glomerular filtration rate before treatment $\overline{0}$ was $10.7 \mathrm{ml} / \mathrm{min} /$ year in our study compared with a mean value of 0 $14.4 \mathrm{ml} / \mathrm{min} /$ year shown by Mogensen ${ }^{6}$ and Viberti et al..$^{14}$ If we $\frac{\sigma^{\circ}}{\frac{5}{\sigma}}$ assume that the rate of decline in glomerular filtration rate (about $\stackrel{\mathbb{Q}}{\Omega}$ $12 \mathrm{ml} / \mathrm{min} /$ year) is linear with time, as suggested above, the median survival time from the onset of persistent proteinuria can be estimated to be about eight to 11 years, depending on the initial. glomerular filtration rate. This estimate agrees closely with the $\vec{\omega}$ observed median survival time of seven to 10 years from the onset of persistent proteinuria in insulin dependent diabetic patients. ${ }^{120}$ If, $\frac{\mathrm{O}}{3}$ however, we assume that the rate of decline in the glomerular filtration rate (about $10 \%$ a year) is exponential, as suggested by 0 Reubi et $a l,{ }^{21}$ a median survival time of more than 25 years will be obtained. Unfortunately, there are no data to support their suggestion. The present median interval between the onset of $\mathrm{T}$ persistent proteinuria and the last investigation is 10.3 years. $\overrightarrow{\vec{A}}$ The findings mentioned above strongly support the validity of $\vec{\omega}$ predicting the glomerular filtration rate from the rate of decline in $\frac{\text { o }}{5}$ glomerular filtration rate before treatment, as we have done in table $\sigma$ III. The predicted values of the glomerular filtration rate were all $\subseteq$ considerably lower than those actually found, and four patients $\vec{D}$ should already have been receiving dialysis.

About $40 \%$ of these and previous patients we have studied ${ }^{22} \stackrel{\odot}{\circ}$ showed a stepwise reduction in glomerular filtration rate of $\geqslant 10 \%$ of . rate before treatment at the start of aggressive antihypertensive 0 treatment. We have shown that the intrinsic vascular (arteriolar) mechanism underlying the normal autoregulation of glomerular $\bar{\partial}$ filtration rate-that is, the fairly constant glomerular filtration rate $\stackrel{0}{\circ}$ that occurs despite quite wide variations in perfusion pressure-is $\varrho$ defective in patients who have diabetic nephropathy. ${ }^{23}$ Closure of $\overrightarrow{\overrightarrow{0}}$ damaged glomeruli caused by ischaemia induced by hypotension 3 may also contribute. These short term observations might suggest that aggressive antihypertensive treatment would be ill advised and harmful to these patients. Fortunately, as discussed above, long term observations clearly indicate that this is not the case. The sudden drop in glomerular filtration rate in the patient in case $10 \div$ after several years of antihypertensive treatment might also be 3 . explained by these mechanisms, as it occurred simultaneously with $\dot{8}$ a reduction in the mean arterial blood pressure, from $112 \mathrm{~mm} \mathrm{Hg}$ to 3 $95 \mathrm{~mm} \mathrm{Hg}$, induced by intensified diuretic treatment (frusemide) 응 required because of oedema. We cannot explain the late drop in glomerular filtration rate in case 8 , as the patient's blood pressure $\mathscr{O}$ was stable, antihypertensive treatment was unchanged, and the $\frac{D}{0}$ results of urine analysis and radioisotope renography were both normal.

In seven of the nine patients who had received long term antihypertensive treatment the rate of decline in glomerular $\bar{\sigma}$ filtration rate was lower during the second period than during the 0 first period of treatment. This improvement cannot be explained by $\underset{\mathbb{D}}{\overparen{D}}$ differences in extrarenal factors, such as mean arterial blood $\stackrel{\oplus}{+}$ pressure, metabolic control, or diet, but may reflect a more $\square$ pronounced protective effect of blood pressure reduction on $\stackrel{\circ}{\circ}$ glomerular filtration in enlarged hyperfiltering glomeruli than in $\stackrel{\mathbb{Q}}{\stackrel{9}{\oplus}}$ damaged hypofiltering glomeruli. A wide range of glomerular $\stackrel{\mathbb{Q}}{\mathbb{Q}}$ lesions, ranging from occluded to enlarged glomeruli, are typically $\underset{\sigma}{\sigma}$ found in patients who have diabetic glomerulosclerosis. ${ }^{24}$

Increased glomerular capillary hydraulic pressure has been $\frac{8}{0}$ shown in normotensive streptozotocin diabetic rats treated with 
insulin. ${ }^{25}$ Other studies have shown that haemodynamic factors, such as arterial hypertension, hyperfiltration, hyperperfusion, and glomerular hypertension, enhance urinary albumin excretion and accelerate the development of glomerulopathy in diabetes mellitus. ${ }^{28-32}$ Conversely, antihypertensive treatment or dietary protein restriction causes a reduction in hyperfiltration and glomerular hypertension, diminishes urinary albumin excretion, and mitigates the haemodynamically induced glomerular lesions. ${ }^{33} 34$ Furthermore, arterial hypertension induces an appreciable increase in glomerular capillary hydraulic pressure in diabetic rats treated with streptozotocin compared with non-diabetic, spontaneously hypertensive rats $(52.6 \mathrm{~mm} \mathrm{Hg} v 43.8 \mathrm{~mm} \mathrm{Hg}){ }^{35}$ This finding provides a likely explanation for the damaging effect of hypertension in diabetes and for the beneficial effect of aggressive antihypertensive treatment on kidney function and albuminuria in diabetic nephropathy. Our present and previous results suggest that albuminuria is largely dependent on pressure, probably because of glomerular hypertension. ${ }^{23} 36$ The haemodynamic findings mentioned above strongly support the hypothesis of Hostetter et al that intrarenal hypertension is an important factor in the development and progression of diabetic glomerulopathy. ${ }^{33}$

Improved metabolic control cannot explain the present results, as postprandial blood glucose concentrations remained unchanged during the study. Furthermore, long term, strict metabolic control achieved by continuous subcutaneous infusion of insulin has failed to influence the glomerular filtration rate and albuminuria in patients who have diabetic nephropathy. ${ }^{15}$

If we assume that the rates of decline in glomerular filtration rate (table II) can be extrapolated to a value of $5 \mathrm{ml} / \mathrm{min} / 1.73 \mathrm{~m}^{2}$, at which dialysis would unequivocally be needed, the median period from the start of antihypertensive treatment to glomerular filtration rate of this value is extended from seven years without treatment to 21 years with treatment.

This study was supported by grants from the Danish Medical Research Council and the Danish Diabetes Association.

\section{References}

1 Deckert T, Poulsen JE, Larsen M. Prognosis of diabetics with diabetes onset before the age of thirty-one. I. Survival, causes of death and complications. Diabetologia 1978;14:363-70.

2 Andersen AR, Christiansen JS, Andersen JK, Kreiner S, Deckert T. Diabetic nephropathy in type 1 (insulin-dependent) diabetes: an epidemiological study. Diabetologia 1983;25:496-501.

3 Borch-Johnsen K, Andersen PK, Deckert T. The effect of proteinuria on relative mortality in type 1 (insulin-dependent) diabetes mellitus. Diabetologia 1985;28:590-6.

4 Berkman J, Rifkin H. Unilateral nodular diabetic glomerulosclerosis (Kimmelstiel-Wilson). Report of a case. Metabolism 1973;22:715-22.

5 Mauer SM, Steffes MW, Azar S, Sandberg SK, Brown DM. The effect of Goldblatt hypertension on development of the glomerular lesions of diabetes mellitus in the rat. Diabetes 1978;27: on dever.

6 Mogensen CE. Long-term antihypertensive treatment inhibiting progression of diabetic nephropathy. BrMed f 1982;285:685-8.

7 Parving H-H, Smidt UM, Fruisberg B, Bonnevie-Nielsen V, Andersen AR. A prospective study of glomerular filtration rate and arterial blood pressure in insulin-dependent diabetics with diabetic nephropathy. Diabetologia 1981;20:457-61.

8 Parving H-H, Andersen AR, Smidt UM, Svendsen PA. Early aggressive antihypertensive reatment reduces rate of decline in kidney function in diabetic nephropathy. Lance $1983 ;$; :1175-9.

Brachner-Mortensen J. A simple method for determination of glomerular filtration rate. Scand $\mathcal{f}$ Clin Lab Invest 1972;30:271-4.

10 Brøchner-Mortensen J, Rødbro P. Selection of routine method for determination of glomerular filtration rate in adult patients. Scand f Clin Lab Invest 1976;36:35-45.

11 Mancini G, Carbonara AO, Heremans JF. Immunochemicat quantitation of antigens by single radial immunodiffusion. Immunochemistry 1965;2:235-54.

12 Björck S, Nyberg G, Mulec H, Granerus G, Herlitz H, Aurell M. Beneficial effects of angiotensin converting enzyme inhibition on renal function in patients with diabetic nephropathy. Br.Med $\mathcal{J}$ 1986;293:471-4.

13 Jones RH, Hayakawa H, Mackay JD, Parsons V, Watkins PJ. Progression of diabetic nephropathy. Lancet 1979;i:1005-6.

14 Viberti GC, Bilous RW, Mackintosh D, Keen H. Monitoring glomerular function in diabetic nephropathy. Am J Med 1983;74:256-64.

15 Viberti GC, Bilous RW, Mackintosh D, Bending JJ, Keen H. Long term correction of hyperglycaemia and progression of renal failure in insulin dependent diabetes. $\mathrm{Br} \mathrm{Med} \mathcal{J}$ 1983;286:598-602.

16 Berglund J, Lins L-E, Lins P-E. Predictability in diabetic nephropathy. Acta Med Scand $1984 ; 215: 263-70$

17 Hasslacher C, Stech W, Wahl P, Ritz E. Blood pressure and metabolic control as risk factors for nephropathy in type 1 (insulin-dependent) diabetes. Diabetologia 1985;28:6-11.

18 Parving $\mathrm{H}-\mathrm{H}$, Andersen AR, Hommel E, Smidt UM. Effect of antihypertensive treatment on diabetic nephropathy in insulin-dependent diabetic patients. In: Friedman EA, L'Esperance FA, eds. Diabetic renal-retinal syndrome. Vol 3. New York: Grune and Stratton, 1986:183-90.

19 Mitch WE, Walser M, Buffington GA, Lemann J. A simple method of estimating progression of chronic renal failure. Lancet 1976;ii: 1326-8.

20 Krolewski AS, Warram JH, Christlieb AR, Busick EJ, Kahn CR. The changing natural history of nephropathy in type 1 diabetes. Am $\mathcal{F}$ Med 1985;78:785-94.

21 Reubi FC, Franz KA, Horber F. Hypertension as related to renal function in diabetes mellitus Hypertension 1985; 7(suppl II):21-8.

22 Parving H-H, Andersen AR, Smidt UM, Friisberg B, Svendsen PA. Reduced albuminuria during early and aggressive antihypertensive treatment of insulin-dependent diabetics with diabetic nephropathy. Diabetes Care 1981;4:459-63.

23 Parving H-H, Kastrup J, Smidt UM, Andersen AR, Feldt-Rasmussen B, Christiansen JS Impaired autoregulation of glomerular filtration rate in type 1 (insulin-dependent) diabetic patients with nephropathy. Diabetologia 1984;27:547-52.

24 Gundersen HJG, Osterby R. Glomerular size and structure in diabetes mellitus. II. Late abnormalities. Diabetologia 1977;13:43-8.

25 Hostetter TH, Troy JL, Brenner BM. Glomerular hemodynamics in experimental diabetes. Kidney Int 1981;19:410-5.

26 Jensen PK, Christiansen JS, Steven K, Parving H-H. Renal function in streptozotocin diabetic rats. Diabetologia 1981;21:409-14

27 Jensen PK, Steven K, Blæhr H, Christiansen JS, Parving H-H. Effects of indomethacin on glomerular hemodynamics in experimental diabetes. Kidney Int 1986;29:490-5.

28 Steffes MW, Brown DM, Mauer SM. Diabetic glomerulopathy following unilateral nephrectomy in the rat. Diabetes 1978;27:35-41.

29 Hostetter TH, Olsson JL, Rennke HG, Venkatachalam MA, Brenner BM. Hyperfiltration in remnant nephrons: a potentially adverse response to renal ablation. Am f Physiol 1981;241: F85-93.

30 Brenner BM. Hemodynamically mediated glomerular injury and the progressive nature of kidney disease. Kidney Int 1983;23:647-55

31 Steffes MW, Brown DM, Mauer SM. The development, enhancement, and reversal of the secondary complications of diabetes mellitus. Human Pathol 1979;10:293-9.

32 Parving H-H, Viberti GC, Keen H, Christiansen JS, Lassen NA. Hemodynamic factors in the genesis of diabetic microangiopathy. Metabolism 1983;32:943-9.

33 Hostetter TH, Rennke HG, Brenner BM. The case for intraren hypertension in the initiation and progression of diabetic and other glomerulopathies. Am f Med 1982;72:375-80

34 Zatz R, Dunn BR, Meyer TW, Anderson S, Rennke HG, Brenner BM. Prevention of diabetic glomerulopathy by pharmacological amelioration of glomerular capillary hypertension. $\mathcal{F} \mathrm{Cln}$ Invest 1986;77:1925-30

35 Bank N, Klose R, Aynedjian HS. Glomerular pressure in rats with diabetes and hypertension. Kidney Int 1985;27:241.

36 Hommel E, Parving H-H, Mathiesen E, Edsberg B, Nielsen MD, Giese J. The effect of captopril treatment on kidney function in insulin dependent diabetic patients with nephropathy. Br Med f 1986;293:467-70.

(Accepled 16 March 1987
The audacity of quack doctors is their chief stock-in-trade. Judging from what a Parisian correspondent states, it is very evident that charlatanism is carried on in Paris in a much more pretentious style than is attempted in this country. Some weeks ago a quack opened a splendid suite of rooms in a building on the Grand Boulevard. He had footmen in plush and pages in livery, distributed handbills by the million, and announced that he had an infallible method of curing hoarseness and diseases of the throat by inhalation. This prince of quacks did not purchase a degree, like many of his compeers, but had himself heralded on bills and in the newspapers as Dr. Pitchitchine, Beloochistan, Member of all the Academies. The big, foreignsounding name, which the doctor had culled at random from an atlas, and the style of his rooms, are said to have produced a great impression on the minds of those unsophisticated people who, despite the enlightenment of the age, still abound, even in the great centres of civilisation; and among those was an actress, who sought this pseudo-throat-healer for hoarseness from which she was suffering. The patient, we are told, went to Pitchitchine's magnificent establishment on the Boulevards. The folding doors were thrown open by a gorgeous flunkey, and the great quack was discovered dressed in Oriental garb. The actress's head was first enveloped in a cloud of cashmere, and she was told to inhale the contents of a tube. She did so, and in a moment fainted away, being nearly suffocated. The quack became alarmed, and had to send for a bona fide medical man, who revived the victim. The actress went home in a cab, and found that, besides being incapacitated from singing, she was hardly able to speak, and had to cancel her engagement. She has consequently brought an action against the pseudonative of Beloochistan, who had simply made her inhale a concoction which contained a large quantity of chloroform. Sahib Pitchitchine is also to be proceeded against by the Parquet for the illegal practice of medicine, and for having worn dazzling decorations to which he had no right. (British Medical fournal 1887;ii:842.) 